\title{
Localisation of a 10q breakpoint within the PAX2 gene in a patient with a de novo $t(10 ; 13)$ translocation and optic nerve coloboma-renal disease
}

\author{
Koji Narahara, Elizabeth Baker, Shigeru Ito, Yuji Yokoyama, Sui Yu, Duncan Hewitt, \\ Grant R Sutherland, Michael R Eccles, Robert I Richards
}

Centre for Medical Genetics, Department of Cytogenetics and Molecular Genetics, Women's and Children's Hospital, Adelaide 5006,

Australia

K Narahara

E Baker

$S$ Yu

D Hewitt

G R Sutherland

R I Richards

\section{Department of}

Pediatrics, Okayama University Medical

School, Okayama 700, Japan

K Narahara

$S$ Ito

Y Yokoyama

Cancer Genetics

Laboratory,

Department of

Biochemistry,

University of Otago,

P O Box 56, Dunedin,

New Zealand

M R Eccles

Correspondence to:

Dr Narahara, Japan.

Received 25 May 1996

Revised version accepted for publication 23 October 1996

\begin{abstract}
We describe a 5 year old boy with a de novo $t(10 ; 13)$ translocation and optic nerve coloboma-renal disease (ONCR). On the basis of GTG banding analysis of prometaphase chromosomes, the patient's karyotype was interpreted as either $46, X Y, t(10 ; 13)(q 24.3 ; q 12.3)$ or $t(10 ; 13)$ (q25.2;q14.1). Fluorescence in situ hybridisation (FISH) studies using a YAC clone containing the PAX2 gene and YAC clones adjoining FRA10B at 10q25.2 showed that the $10 \mathrm{q}$ breakpoint had occurred just within the PAX2 gene and was proximal to FRA10B. These FISH results suggest that the translocation causes a disruption of the PAX2 gene and leads to ONCR, in agreement with the recent reports of PAX2 mutations in two unrelated families with ONCR. Furthermore, we refined the regional mapping of the human PAX2 gene to the junction of bands 10q24.3 and 10q25.1.

$(\mathcal{M}$ Med Genet 1997;34:213-216)
\end{abstract}

Keywords: optic nerve coloboma-renal disease; PAX2; $\mathrm{t}(10 ; 13)$ translocation.

Optic nerve coloboma-renal disease (ONCR, MIM No 120330) is a newly established syndrome. ${ }^{1-3}$ It is characterised by autosomal dominant inheritance of a "morning glory" optic disc anomaly, resulting in loss of visual acuity and defective visual fields. A substantial number of affected patients have also had associated chronic renal failure, chronic glomerulonephritis, or renal hypoplasia.

Paired box (PAX) genes are members of the superfamily of developmental control genes that encode transcription factors containing a paired DNA binding domain. ${ }^{4}$ There are nine human PAX genes, and mutations in two of them (PAX3 and PAX6) are known to cause developmental defects (Waardenburg syndrome types I and III and aniridia). ${ }^{56}$ Since the murine Pax 2 gene is expressed in the developing kidney, optic cup, otic vesicle, and other parts of the central nervous system, ${ }^{7}$ Sanyanusin et al ${ }^{\beta}$ evaluated PAX2 in two unrelated families with ONCR, and discovered mutations which resulted in a change of the PAX2 reading frame with a subsequent truncated PAX2 protein. ${ }^{8}{ }^{9}$
We report a 5 year old boy with a de novo $t(10 ; 13)$ translocation and ONCR. Fluorescence in situ hybridisation (FISH) with a YAC clone containing the PAX2 gene showed that the $10 \mathrm{q}$ breakpoint lies within the PAX2 gene, suggesting that the disruption of the PAX2 gene may cause ONCR. Furthermore, we refined the regional mapping of the human PAX2 gene to the junction of bands10q24.3 and $10 \mathrm{q} 25.1$.

\section{Methods}

CASE REPORT

The proband was the first child of healthy and non-consanguineous parents. He was born at term after an uneventful pregnancy. His birth weight was $3202 \mathrm{~g}$, length $51 \mathrm{~cm}$, and head circumference $34 \mathrm{~cm}$. His mother was 26 years old and his father 28 years old. There was no family history of renal disease or ophthalmological abnormalities. Bilateral strabismus and nystagmus were noticed at birth, and he was diagnosed as having bilateral optic nerve colobomas. He did not show any other abnormal findings, and his subsequent psychomotor development was normal.

At the age of 5 years 2 months, he had an acute episode of sore throat and fever. Streptoccocal infection was suspected and he was treated with ampicillin. Two weeks later, he was referred to hospital because of proteinuria. Physical examination showed a height of 109 $\mathrm{cm}$ (30th centile) and weight of $20.0 \mathrm{~kg}$ (50th centile). He had bilateral nystagmus, amblyopia, and cataract, but otherwise appeared normal. There was no oedema, oliguria, or hypertension. Ophthalmological examination showed bilateral large optic discs with temporal colobomas and an anomalous vascular pattern. Urine analysis showed moderate proteinuria $(1.0 \mathrm{~g} /$ day $)$, but urinary sediments were unremarkable. The urinary levels of $\mathrm{N}$-acetyl glucosaminidase $(10.6 \mathrm{IU} / \mathrm{l})$ and $\alpha-2$ microglobulin $(239 \mathrm{ng} / \mathrm{ml})$ were raised. Blood chemistry showed mild renal dysfunction with blood urea-N of $38.5 \mathrm{mg} / \mathrm{dl}$, creatinine of 1.3 $\mathrm{mg} / \mathrm{dl}$, and creatinine clearance of $56.5 \mathrm{ml} / \mathrm{min}$. Serum levels of total protein, complement, and immunoglobulins were normal. There was no serological evidence of streptococcal infection. Ultrasonography showed normal sized kidneys (left: $6.5 \times 3.0 \mathrm{~cm}$, right: $6.0 \times 2.0 \mathrm{~cm}$ ), and voiding cystourethrography showed no 

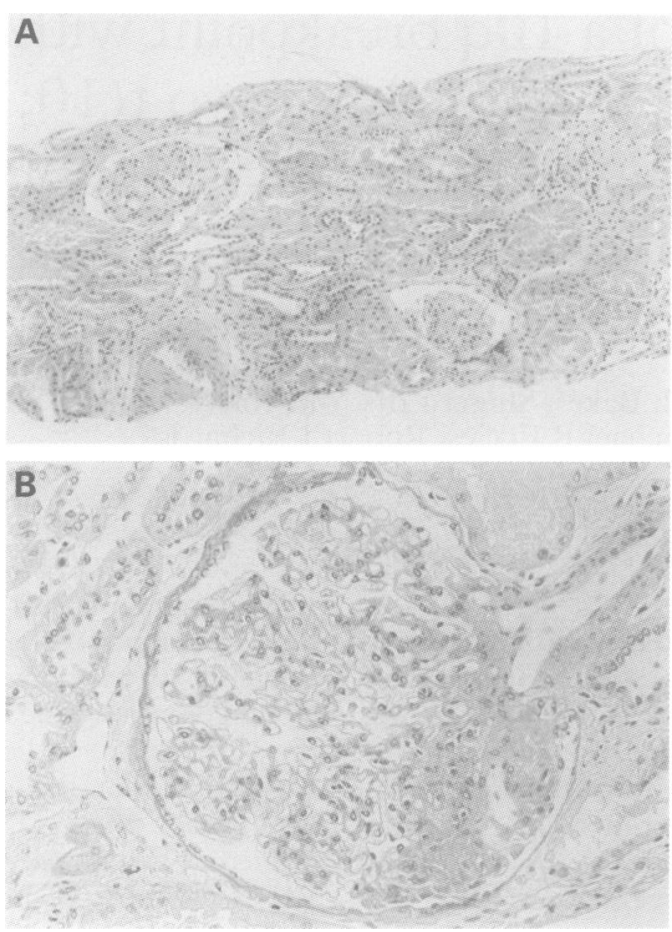

Figure 1 Renal histology of the patient: a low power field magnification $(A)$ and a high power field magnification (B) with PAS staining.

anatomical abnormalities or vesicoureteral reflux. To evaluate the cause of proteinuria, percutaneous kidney biopsy was performed. Microscopic examination of the biopsy disclosed striking atrophy of the proximal and distal renal tubules and interstitial fibrosis but with little inflammatory cell infiltration of the interstitium (fig 1A). Three of eight glomeruli examined showed focal segmental sclerosis with mild mesangeal proliferation (fig 1B). Immunofluorescence studies did not show any deposit of immunoglobulins, fibrinogen, or complement.

\section{CYTOGENETIC STUDY}

Peripheral blood lymphocytes were stimulated by phytohaemagglutinin and cultured using standard procedures. Prometaphase cells were collected by the addition of ethidium bromide to cultures two hours before harvest. Cytogenetic analyses included GTG and QFQ banding.

\section{FLUORESCENCE IN SITU HYBRIDISATION (FISH)} STUDY

Slides were prepared from the patient's lymphoblastoid cells transformed by Epstein-Barr virus. The following YAC and cDNA probes were used for FISH: y868H11 is a YAC clone whose locus is just proximal to FRA10B, y937A6 is a YAC clone whose locus is just distal to FRA10B, 29C-D5 is a YAC clone $(-100$ $\mathrm{kb})$ which contains exons 4-12 of the human PAX2 gene, phuPAX2 is a cDNA clone which contains approximately the 3 ' half of the PAX2 coding region (nucleotide 842 , in exon 3 , to 3420 ) and $3^{\prime}$ untranslated region, and pPAX2N1 which contains the 5' untranslated and all the PAX2 coding region (nucleotide $1-1820) .^{10}$ FISH analysis was as described except that chromosomes were stained before
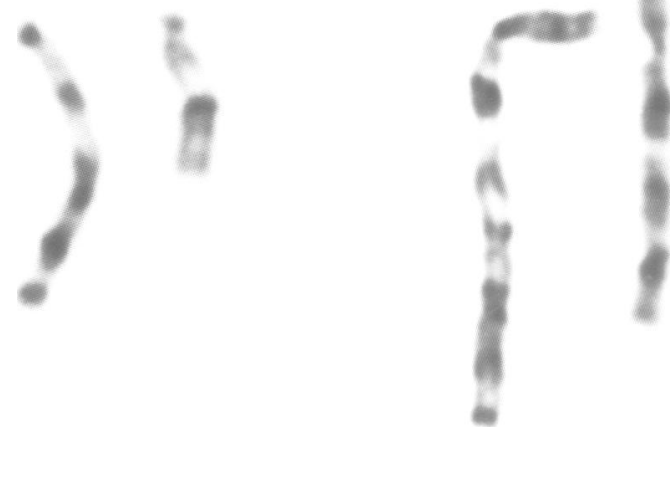

$13 \operatorname{der}(13)$

$\operatorname{der}(10) 10$

Figure 2 Partial $G$ banded karyotype of the patient.

analysis with both propidium iodide (as counterstain) and DAPI (for chromosome identification). ${ }^{11}$ Images of metaphase preparations were captured by a CCD camera and computer enhanced.

SOUTHERN BLOT ANALYSIS

Five micrograms of genomic DNA digested with EcoRI, BamHI, and KpnI were electrophoresed on $1.0 \%$ agarose gels, Southern blotted, and hybridised with $\alpha-{ }^{32} \mathrm{P}$ oligolabelled cDNA probe for PAX2, pPAX2N1. Hybridisation and washing conditions were essentially the same as previously described. ${ }^{10}$

\section{Results}

CYTOGENETIC STUDY

Cytogenetic analysis of the patient showed a reciprocal translocation between the long arms of chromosomes 10 and 13. From GTG banding of prometaphase chromosomes, his karyotype was interpreted either as $46, \mathrm{XY}$, $\mathrm{t}(10 ; 13)(\mathrm{q} 24.3 ; \mathrm{q} 12.3)$ or as $46, \mathrm{XY}, \mathrm{t}(10 ; 13)$ (q25.2;q14.1) (fig 2). The translocation appeared to be balanced. Both parents had normal chromosomes. The QFQ polymorphism pattern of chromosomes 13 was not informative for the parental origin of the translocation.

FISH STUDY

Results of FISH studies are shown in table 1. The two YACs adjoining FRA10B hybridised to the normal chromosome 10 and to the der(13) chromosome. This indicated that the breakpoint of the translocation is proximal to FRA10B at 10q25.2. On the other hand, YAC 29C-D5 hybridised to the normal chromosome 10 and to both the $\operatorname{der}(10)$ and $\operatorname{der}(13)$ chromosomes (fig 3A). This indicated that the inserted segment of the YAC 29C-D5 spanned the patient's $10 \mathrm{q}$ translocation breakpoint. To sublocalise the $10 \mathrm{q}$ breakpoint, we hybridised the patient's chromosomes with the cDNA clones of the PAX2 gene. The whole cDNA clone, pPAX2N1, hybridised to the normal chromosome 10 and to both the $\operatorname{der}(10)$ and $\operatorname{der}(13)$ chromosomes, while the more $3^{\prime}$ cDNA clone, phuPAX2, hybridised to the 
Table 1 Results of FISH of $t(10 ; 13)$

\begin{tabular}{lllll}
\hline & \multicolumn{2}{l}{ No of cells with FISH signal } & \\
\cline { 2 - 4 } Probes & $\begin{array}{l}\text { Chromosome } \\
10\end{array}$ & $\operatorname{der}(10)$ & $\operatorname{der}(13)$ & $\begin{array}{l}\text { No of cells } \\
\text { analysed }\end{array}$ \\
\hline y868H11 & 15 & 0 & 15 & 15 \\
y937A6 & 14 & 0 & 14 & 14 \\
29C-D5 & 12 & 12 & 12 & 12 \\
phuPAX2 & 10 & 0 & 15 & 16 \\
pPAX2N1 & 16 & 7 & 17 & 23 \\
\hline
\end{tabular}

*Sensitivity and specificity was such that $60 \%$ to $100 \%$ of all metaphases (depending on the size of the probe) had fluorescen signal on chromosome 10 , or a derivative, with little or no background.

normal chromosome 10 and to the der(13) chromosome. These results suggest that the translocation breakpoint is located somewhere in the middle of the PAX2 gene. DAPI staining showed that the PAX2 probes hybridised to band $10 \mathrm{q} 24.3$ of the normal chromosome 10 (fig 3B). Therefore, the karyotype can be designated 46,XY, $\mathrm{t}(10 ; 13)$ (q24.3;q12.3).

SOUTHERN BLOT ANALYSIS

Southern blot analysis with the cDNA probe, pPAX2N1, containing all the coding region of the PAX2 gene did not show any band shift or reduction in band intensity on the patient's genomic DNA digested with EcoRI, BamHI, and $K p n I$ (data not shown). These findings indicate that the breakpoint did not involve any exon or the translocation did not cause any deletion large enough to be detected by the PAX2 cDNA.

\section{Discussion}

We described here the clinical, cytogenetic, and molecular findings of a patient with a de novo apparently balanced $t(10 ; 13)$ translocation and ONCR. Cosegregation of chromosomal rearrangements in patients with known diseases or disorders caused by dominant gene mutations has facilitated the mapping and positional cloning of the genes responsible. ${ }^{12}$ The present patient is the first case of ONCR associated with a constitutional chromosome abnormality. FISH studies showed that the $10 \mathrm{q}$ breakpoint had occurred within the PAX2 gene and produced its disruption. The FISH results in
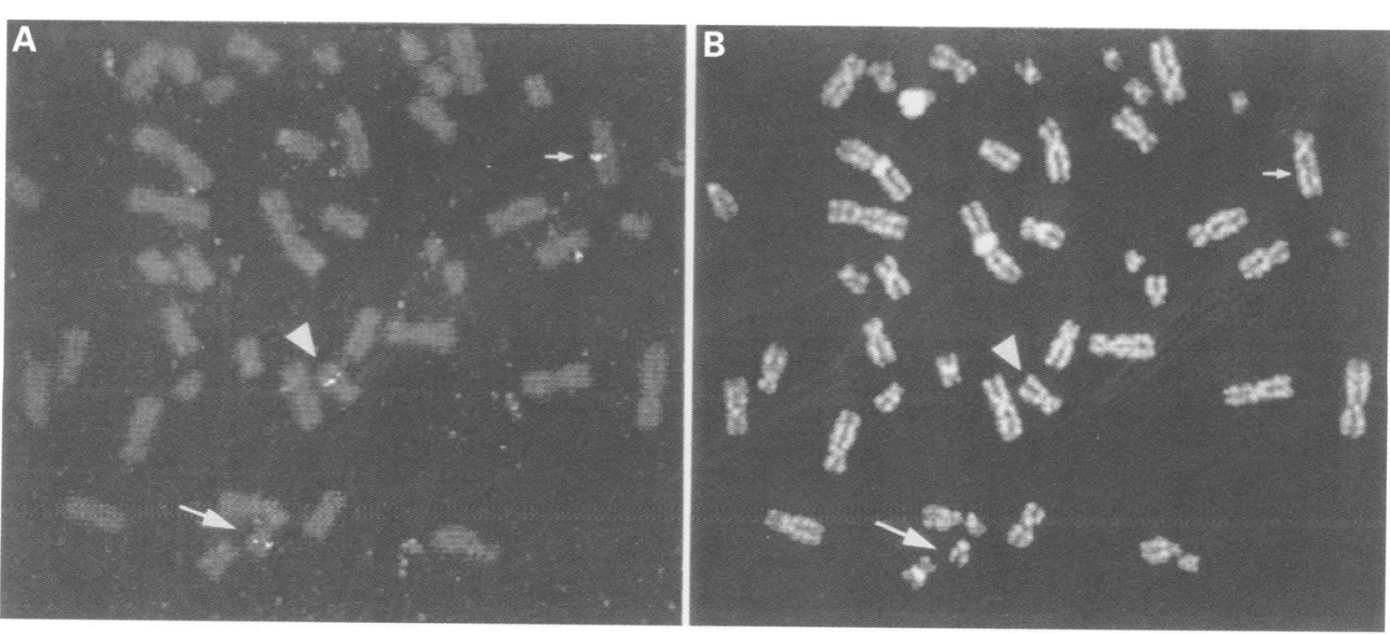

Figure 3 Metaphases from the patient showing FISH with YAC 29C-D5. (A) Chromosomes stained with propidium iodide showing hybridisatioin of the probe to the normal chromosome 10 (arrowhead), the derivative chromosome 10 (small arrow), and the derivative chromosome 13 (large arrow). (B) The same metaphase as in $(A)$ stained with DAPI for
chromosome identification. 
in the threshold or dosage sensitivity of different tissues, which might be influenced by purely stochastic factors as well as genetic background. Alternatively, the overlapping PAX8 expression in the fetal kidney could partially compensate for deficiencies of PAX2 expression during nephrogenesis. ${ }^{8}$

As shown in two other cases reported by Weaver $e t a l^{\beta}$ and the case reported here, the renal histopathology of ONCR consists of interstitial fibrosis and tubular atrophy but with no evident infiltration of inflammatory cells at the early stage of chronic renal failure, and diffuse interstitial fibrosis and glomerulosclerosis with mesangeal proliferation and electron dense deposits at the later stage. ${ }^{3}$ It has been widely accepted that vesicoureteral reflux and asymptomatic urinary infection cause chronic renal failure with a similar histology to that seen in ONCR. ${ }^{17}$ In our patient, however, this mechanism seems unlikely, because there was no vesicoureteral reflux or inflammatory cell infiltration in the interstitium. Little is known about the targets of the PAX2 protein or its downstream genes. The knowledge of how PAX2 mutations can affect the downstream genes and result in end stage renal disease is necessary for developing therapeutic interventions, which could slow progression of renal failure in ONCR.

There has been controversy about the localisation of the PAX2 gene: FISH studies have assigned it to $10 \mathrm{q} 25,{ }^{18}$ and somatic cell hybrid mapping to $10 \mathrm{q} 22.1-\mathrm{q} 24.3{ }^{10}$ We showed that the PAX2 gene lies within the 10q24.3 band and is proximal to FRA10B at 10q25.2. These results led us to conclude that the PAX2 gene is at the junction of bands $10 \mathrm{q} 24.3$ and $10 \mathrm{q} 25.1$, which is in agreement with the report of the First International Workshop on Human Chromosome 10 Mapping. ${ }^{19}$ This study was supported in part by grants from the Japanese
Ministry of Health and Welfare and the Japanese Ministry of Ministry of Health and Welfare and the Japanese Ministry of Education, Science and Culture to K Narahara, the Australian
National Health and Medical Research Council to G R Sutherland and R I Richards, and the Health Research Council and land and R I Richards, and the Health Research Council and
Cancer Society of New Zealand to M R Eccles. D Hewitt is a Wellcome Travelling Fellow.
1 Rieger G. Zum Krankheitsbild der Handmannschen Sehnervenanomalie: Winden-bluten (Morning Glory) Syndrom? Klin Monatsbl Augenheilkd 1977;170:697-706.

2 Karcher H. Zum Morning Glory Syndrom. Klin Monatsbl Augenheilkd 1979;175:835-40.

3 Weaver RG, Cashwell LF, Lorentz W, et al. Optic nerve coloboma associated with renal disease. Am $\mathcal{F}$ Med Genet 1988;29:597-605.

4 Strachan T, Read AP. PAX genes. Curr Opin Genet Dev 1994;4:427-38.

5 Tassabehji M, Read AP, Newton VE, et al. Waardenburg's syndrome parents have mutions in the human homologue of the Pax-3 paired box gene. Nature 1992;355:635-6.

6 Ton CCT, Hirvonen $\mathrm{H}$, Miwa $\mathrm{H}$, et al. Positional cloning and characterization of a paired box- and homeoboxcontaining gene from the aniridia region. Cell 1991;67: 1059-74.

7 Dressler GR, Deutsch U, Choudhury K, et al. Pax 2, a new murine paired-box-containing gene and it expression in the developing excretory system. Development 1990;109:787 95

8 Sanyanusin P, Schimmenti LA, McNoe LA, et al. Mutation of the PAX2 gene in a family with optic nerve colobomas, renal anomalies and vesicoureteral reflux. Nat Genet 1995; 9:358-64.

9 Sanyanusin P, McNoe LA, Sullivan MJ, et al. Mutation of PAX2 in two siblings with renal-coloboma syndrome. Hum Mol Genet 1995;4:2183-4

10 Eccles MR, Wallis LJ, Fidler AE, et al. Expression of the PAX2 gene in human fetal kidney and Wilms' tumor. Cell Growth Diff 1992;3:279-89.

11 Callen DF, Baker E, Eyre HJ, et al. Reassessment of two apparent deletions of chromosome $16 \mathrm{p}$ to an ins $(11 ; 16)$ and a t $(1 ; 16)$ by chromosome painting. Ann Genet (Paris) 1990;33:219-21.

12 Schinzel A, McKusick VA, Francomano C. Report of the Committee for Clinical Disorders and Chromosome Aberrations. In: Cuticchia AJ, Pearson PL, eds. Human gene mapping 1994. A compendium. Baltimore: Johns Hopkins University Press, 1995.

13 Budarf ML, Collins J, Gong W, et al. Cloning a balanced translocation associated with DiGeorge syndrome and identification of a disrupted candidate gene. Nat Genet 1995;10:269-78.

14 Fantes J, Redeker B, Bree $M$, et al. Aniridia-associated cytogenetic rearrangements suggest that a position effect may cause the mutant phenotype. Hum Mol Genet 1995; 415-22.

15 Legros y Carrenard JR, Cortes FM, Sanchez JM. Sindrome de "ojo de gato" con agenesia renal derecha. Aportacion de un caso y revision de la literatura. An Esp Pediatr 1992;36 317-19.

16 Schimmenti LA, Pierpont ME, Carpenter BLM, et al. Autosomal dominant optic nerve colobomas, vesicoureteral reflux, and renal anomalies. Am f Med Genet 1995;59:2048.

17 Becker GJ, Kincaid-Smith P. Reflux nephropathy: the glomerular lesion and progression of renal failure. Pediatr Nephrol 1993;7:365-9.

18 Stapleton P, Weith A, Urbanek P, et al. Chromosomal localizatiion of seven PAX genes and cloning of a novel family member, PAX-9. Nat Genet 1993;3:292-8.

19 Moschonas NK, Spurr NK, Mao J. Report of the first international workshop on human chromosome 10 mapping. Cytogenet Cell Genet 1996;72:99-112. 